\title{
Foliar and topdressing application of nitrogen to the common bean crop
}

\author{
Tailene Elisa Kotz-Gurgacz ${ }^{(1)}$, Rogério Peres Soratto ${ }^{(1)}$ and Fernando Vieira Costa Guidorizzi(1)
}

(1)Universidade Estadual Paulista "Júlio de Mesquita Filho", Faculdade de Ciências Agronômicas, Departamento de Produção e Melhoramento Vegetal, Campus de Botucatu, Avenida Universitária, no 3.780, Fazenda Experimental Lageado, CEP 18610-034 Botucatu, SP, Brazil. E-mail: taileneelisa@hotmail.com, rogerio.soratto@unesp.br, fernando_guidorizzi@hotmail.com

\begin{abstract}
The objective of this work was to evaluate the effect of applying $\mathrm{N}$ sources to leaves and $\mathrm{N}$ rates to the soil on the growth, $\mathrm{N}$ uptake, and grain and crude protein yields of the common bean (Phaseolus vulgaris) crop. Three experiments - two irrigated and one rainfed - were conducted during the 2012/2013 agricultural season, in a randomized complete block design with four replicates. The treatments consisted of the application of: four $\mathrm{N}$ rates $\left(0,45,90\right.$, and $\left.180 \mathrm{~kg} \mathrm{ha}^{-1}\right)$ to the soil, as topdressing in the $\mathrm{V}_{4}$ stage; and five $\mathrm{N}$ sources/rates - i.e., control, without foliar $\mathrm{N}$ application; $2.5 \mathrm{~kg} \mathrm{ha}^{-1} \mathrm{~N}$ as conventional urea (N-CU); $5.0 \mathrm{~kg}$ $\mathrm{ha}^{-1} \mathrm{~N}-\mathrm{CU} ; 2.5 \mathrm{~kg} \mathrm{ha}^{-1} \mathrm{~N}$ as slow-release urea-formaldehyde (N-SR); and $5.0 \mathrm{~kg} \mathrm{ha}^{-1} \mathrm{~N}-\mathrm{SR}$ - to leaves, in the $\mathrm{R}_{5}$ stage. Soil $\mathrm{N}$ fertilization, using rates between 124 and $180 \mathrm{~kg} \mathrm{ha}^{-1}$, increases shoot $\mathrm{N}$ content and uptake, number of pods per plant, grain yield, and protein content and yield. Regardless of the growing environment and $\mathrm{N}$ application to the soil, the foliar supply of $\mathrm{N}$ as slow-release urea-formaldehyde increases grain and protein yields, whereas the greatest rate of $\mathrm{N}$ as conventional urea also increases grain yield.
\end{abstract}

Index terms: Phaseolus vulgaris, foliar fertilization, nitrogen fertilization, slow release, urea-formaldehyde.

\section{Aplicação de nitrogênio via foliar e em cobertura na cultura do feijoeiro comum}

Resumo - O objetivo deste trabalho foi avaliar o efeito da aplicação de fontes de $\mathrm{N}$ via foliar e de doses de $\mathrm{N}$ via solo no crescimento, na absorção de $\mathrm{N}$ e na produtividade de grãos e de proteína bruta da cultura do feijão comum (Phaseolus vulgaris). Foram conduzidos três experimentos - dois em condição irrigada e um em sequeiro - no ano agrícola 2012/2013, em delineamento de blocos ao acaso, com quatro repetições. Os tratamentos consistiram da aplicação de: quatro doses de $\mathrm{N}$ via solo $\left(0,45,90 \mathrm{e} 180 \mathrm{~kg} \mathrm{ha}^{-1}\right)$, em cobertura, no estádio $\mathrm{V}_{4}$; e cinco fontes/doses de $\mathrm{N}$ via foliar - i.e., testemunha, sem $\mathrm{N}$ via foliar; $2,5 \mathrm{~kg} \mathrm{ha}^{-1}$ de $\mathrm{N}$ na forma de ureia convencional (N-UC); 5,0 $\mathrm{kg} \mathrm{ha}^{-1}$ de N-UC; $2,5 \mathrm{~kg} \mathrm{ha}^{-1}$ de $\mathrm{N}$ na forma de ureia-formaldeído de liberação lenta (N-LL); e 5,0 $\mathrm{kg} \mathrm{ha}^{-1}$ de N-LL -, no estádio $\mathrm{R}_{5}$. A adubação nitrogenada via solo, com doses entre 124 e $180 \mathrm{~kg} \mathrm{ha}^{-1}$, aumenta o teor e o acúmulo de $\mathrm{N}$ na parte aérea, o número de vagens por planta, a produtividade de grãos, e o teor e a produtividade de proteína. Independentemente do ambiente de cultivo e da aplicação de $\mathrm{N}$ via solo, o fornecimento de $\mathrm{N}$ na forma de ureia-formaldeído de liberação lenta via foliar aumenta a produtividade de grãos e de proteína, enquanto a aplicação da maior dose de $\mathrm{N}$ na forma de ureia convencional também aumenta a produtividade de grãos.

Termos para indexação: Phaseolus vulgaris, adubação foliar, adubação nitrogenada, liberação lenta, ureiaformaldeído.

\section{Introduction}

Common bean (Phaseolus vulgaris L.) has a great importance for agriculture and is a high-protein staple food in Brazil. The country is one of the largest producers and consumers of bean worldwide (FAO, 2017), with a production of approximately 2.5 million tons of grains on 2.8 million hectares (Conab, 2017).

Nitrogen is the nutrient taken up in the greatest amount by the common bean crop (Perez et al., 2013; Soratto et al., 2013); therefore, its supply at suitable rates and times is fundamental for obtaining a high grain yield (Soratto et al., 2011, 2014, 2017; Amaral et al., 2016).

The main method of supplying $\mathrm{N}$ to common bean has been through mineral fertilization applied to the soil, partly in the sowing furrow and partly topdressed or via an irrigation system. The $\mathrm{N}$ rates applied to the common bean crop may vary according to growing seasons, cropping history, previous crop, soil management system, and cultivar (Bordin et al., 2003; Soratto et al., 2004; Fornasieri Filho et al., 2007; Maia

Pesq. agropec. bras., Brasília, v.53, n.12, p.1329-1337, Dez. 2018 DOI: 10.1590/S0100-204X2018001200005 
et al., 2017). Soratto et al. (2004) observed an increase in common bean grain yield with the application of up to 129 and $182 \mathrm{~kg} \mathrm{ha}^{-1}$ topdressing $\mathrm{N}$ under conventional soil tillage and a newly established no-tillage system, respectively. Kaneko et al. (2010) and Soratto et al. (2017) obtained increases in common bean grain yield with the application of up to $180 \mathrm{~kg} \mathrm{ha}^{-1} \mathrm{~N}$. Amaral et al. (2016) evaluated the cultivation of common bean under different straw mulching - corn (Zea mays L., corn + Urochloa ruziziensis (R.Germ. \& C.M.Evrard) Morrone \& Zuloaga, and U. ruziziensis - and found increases in grain yield with the application of up to $136 \mathrm{~kg} \mathrm{ha}^{-1} \mathrm{~N}$.

The supply of $\mathrm{N}$ to common bean can be supplemented by foliar application, and the main source used for this purpose is urea (Almeida et al., 2000; Soratto et al., 2011). According to Soratto et al. (2013), the time of greatest requirement/uptake of $\mathrm{N}$ by common bean occurs between the end of the $R_{5}$ stage and the beginning of the $\mathrm{R}_{7}$ stage. Therefore, the supply of $\mathrm{N}$ in the reproductive stages of the common bean crop can increase grain yield and protein content. Soratto et al. (2011), using a solution with $10 \%$ urea (i.e., $4.5 \% \mathrm{~N}$ ), observed that foliar $\mathrm{N}$ application in the $\mathrm{R}_{5}$ (pre-flowering) or $\mathrm{R}_{5}+\mathrm{R}_{7}$ (pod formation) stages increased the grain weight and grain and protein yields of the common bean crop, but only without topdressing $\mathrm{N}$ fertilization. However, foliar-applied $\mathrm{N}$ can damage the leaves of the common bean plant depending on the urea concentration in the solution and on the time of application (Almeida et al., 2000).

In addition to the conventional sources, there are slow- or controlled-release $\mathrm{N}$ fertilizers on the market. Among these, Coron stands out as a foliar fertilizer that contains slow-release urea-formaldehyde (or urea-polymethylene) and a portion of fast-release $\mathrm{N}$. According to Roberts et al. (2006), Coron has low phytotoxicity and its chemical composition allows it to remain in a liquid state on the leaf surface for a longer period of time than conventional fertilizers, such as urea, leading to a greater $\mathrm{N}$ uptake by the leaves. In cotton (Gossypium hirsutum L.), Roberts et al. (2006) reported that the foliar application of the product Coron, together with the reduction of soil $\mathrm{N}$ fertilization, resulted in a higher lint yield and economic return than the application of only foliar urea. It should be noted that, although foliar $\mathrm{N}$ application is a practice routinely adopted by producers, studies on it are scarce, and there are no known researches on the effect of the slow-release source Coron on the common bean crop.

The objective of this work was to evaluate the effect of applying $\mathrm{N}$ sources to leaves and $\mathrm{N}$ rates to the soil on the growth, $\mathrm{N}$ uptake, and grain and crude protein yields of the common bean crop.

\section{Materials and Methods}

Three field experiments - two under irrigated conditions and one rainfed - were conducted during the 2012/2013 crop year, in the municipality of Botucatu, in the state of São Paulo, Brazil $\left(22^{\circ} 51^{\prime} \mathrm{S}, 48^{\circ} 26^{\prime} \mathrm{W}\right.$, at an altitude of $740 \mathrm{~m}$ ). The first (irrigated 2012) was carried out in the rainy season, and the second (rainfed 2013) and third (irrigated 2013) in the dry season, but in different areas with different cropping histories and crop rotations. The climatic data recorded during the experimental period are shown in Figure 1. According to Köppen's classification, the predominant climate in the region is Cwa.

The soil of the areas used for the experiments irrigated 2012 and irrigated 2013 was classified as a Nitossolo Vermelho distroférrico, i.e., a Typic Rodudalf, whereas the one for rainfed 2013 was classified as a Latossolo Vermelho distroférrico, i.e., a Typic Haplorthox (Santos et al., 2013). The experimental areas were managed in the no-tillage system; the experiments irrigated 2012 and irrigated 2013 were conducted in succession to pearl millet [Pennisetum glaucum (L.) R.Br.] and rainfed 2013 in succession to $U$. ruziziensis. Before common bean was sown, soil samples were collected from the $0.0-0.20-\mathrm{m}$ layer. In the area used for the experiment irrigated 2012, the soil had the following characteristics: $26 \mathrm{~g} \mathrm{dm}^{-3}$ organic matter; $\mathrm{pH}\left(\mathrm{CaCl}_{2}\right)$ 5.6; $50 \mathrm{mg} \mathrm{dm}^{-3} \mathrm{P}_{\text {resin }} ; 4.7,43,21$, and $31 \mathrm{mmol}_{\mathrm{c}} \mathrm{dm}^{-3} \mathrm{~K}$, $\mathrm{Ca}, \mathrm{Mg}$, and $\mathrm{H}+\mathrm{Al}$, respectively; base saturation (BS) of $69 \%$; and 240,110 , and $650 \mathrm{~g} \mathrm{~kg}^{-1}$ sand, silt, and clay, respectively. In the experiment rainfed 2013, the soil characteristics were as follows: $37 \mathrm{~g} \mathrm{dm}^{-3}$ organic matter; $\mathrm{pH}\left(\mathrm{CaCl}_{2}\right) 4.4 ; 37 \mathrm{mg} \mathrm{dm}^{-3} \mathrm{P}_{\text {resin }} ; 4.1,26,12$, and $67 \mathrm{mmol}_{\mathrm{c}} \mathrm{dm}^{-3} \mathrm{~K}, \mathrm{Ca}, \mathrm{Mg}$, and $\mathrm{H}+\mathrm{Al}$, respectively; BS of $39 \%$; and 310,93 , and $597 \mathrm{~g} \mathrm{~kg}^{-1}$ sand, silt, and clay, respectively. In the area used for the experiment irrigated 2013, the characteristics of the soil were: $35 \mathrm{~g}$ $\mathrm{dm}^{-3}$ organic matter; $\mathrm{pH}\left(\mathrm{CaCl}_{2}\right) 5.3 ; 41 \mathrm{mg} \mathrm{dm}^{-3} \mathrm{P}_{\text {resin }}$; 4.7, 47, 24, and $37 \mathrm{mmol}_{\mathrm{c}} \mathrm{dm}^{-3} \mathrm{~K}, \mathrm{Ca}, \mathrm{Mg}$, and $\mathrm{H}+\mathrm{Al}$, 
respectively; BS of $67 \%$; and 245,112 , and $643 \mathrm{~g} \mathrm{~kg}^{-1}$ sand, silt, and clay, respectively.

In all experiments, the experimental design was a randomized complete block with four replicates. The treatments consisted of the application of: four $\mathrm{N}$ rates $\left(0,45,90\right.$, and $\left.180 \mathrm{~kg} \mathrm{ha}^{-1} \mathrm{~N}\right)$ to the soil; and five $\mathrm{N}$ sources/rates - control, without foliar $\mathrm{N}$ application; $2.5 \mathrm{~kg} \mathrm{ha}^{-1} \mathrm{~N}$ as conventional urea (N-CU); $5.0 \mathrm{~kg} \mathrm{ha}^{-1}$ $\mathrm{N}-\mathrm{CU} ; 2.5 \mathrm{~kg} \mathrm{ha}^{-1} \mathrm{~N}$ as slow-release urea-formaldehyde (N-SR); and $5.0 \mathrm{~kg} \mathrm{ha}^{-1} \mathrm{~N}-\mathrm{SR}$ - to leaves. The commercial product used for the supply of N-SR was Coron $25-0-0$ plus $0.5 \% \mathrm{~B}$ (Helena Chemical Company, Collierville, TN, USA), a slow-release fertilizer based on a resinous urea-formaldehyde solution, with $25 \%$ $\mathrm{N}$ and $0.5 \% \mathrm{~B}(\mathrm{~m} / \mathrm{m})$; according to the manufacturer,
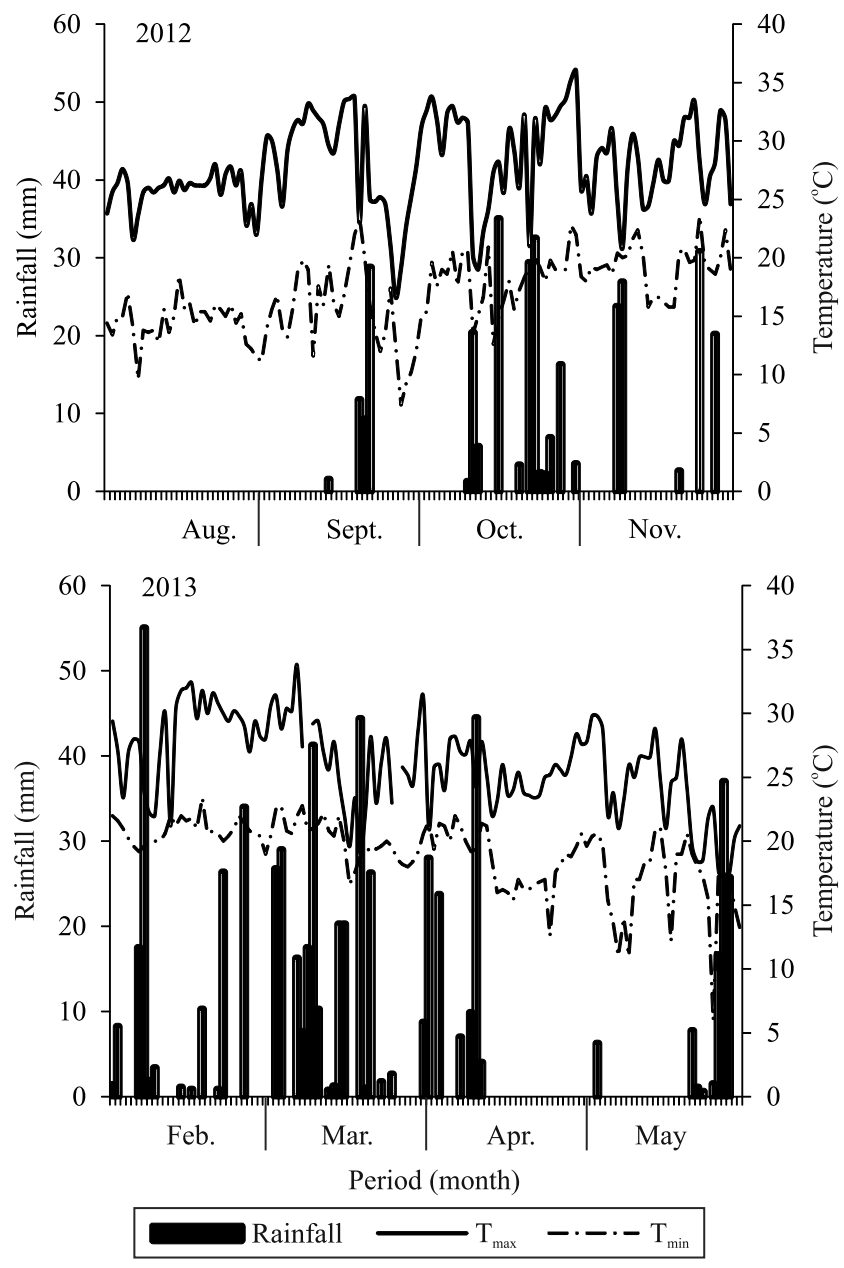

Figure 1. Daily rainfall, maximum temperature, and minimum temperature recorded at the experimental area from August to November 2012 and from February to May 2013.
$6.25 \%$ of the $\mathrm{N}$ is slow release and $18.75 \%$ is immediate release. Each plot consisted of five 6-m long bean rows, $0.45 \mathrm{~m}$ apart. For the evaluations, the three central rows were considered, and $0.5 \mathrm{~m}$ was excluded at the end of each row.

The plants present in the experimental areas were desiccated with $1.44 \mathrm{~kg}$ a.i. $\mathrm{ha}^{-1}$ of the herbicide glyphosate five days before common bean sowing. The common bean cultivar Pérola was mechanically sown on $8 / 20 / 2012$ for the experiment irrigated 2012, on $2 / 14 / 2013$ for rainfed 2013, and on $2 / 21 / 2013$ for irrigated 2013, with 13 seeds distributed per row meter. The seeds were treated with carboxin+thiram, thiamethoxam, and cobalt + molybdenum. For sowing fertilization of the experiment irrigated $2012,13 \mathrm{~kg} \mathrm{ha}^{-1}$ $\mathrm{N}, 60 \mathrm{~kg} \mathrm{ha}^{-1} \mathrm{P}_{2} \mathrm{O}_{5}$, and $40 \mathrm{~kg} \mathrm{ha}^{-1} \mathrm{~K}_{2} \mathrm{O}$ were applied, with urea, triple superphosphate, and potassium chloride as sources, respectively. In the experiments rainfed 2013 and irrigated 2013, $180 \mathrm{~kg} \mathrm{ha}^{-1}$ of the 8-28-16 $\mathrm{N}-\mathrm{P}_{2} \mathrm{O}_{5}-\mathrm{K}_{2} \mathrm{O}$ fertilizer were applied. In the experiment irrigated 2012, seedling emergence occurred nine days after sowing (DAS), whereas in rainfed 2013 and irrigated 2013 emergence occurred eight DAS.

Topdressing $\mathrm{N}$ fertilization (ammonium nitrate) was applied on 9/26/2012 for the experiment irrigated 2012 , on $3 / 9 / 2013$ for rainfed 2013 , and on $3 / 14 / 2013$ for irrigated 2013, when the common bean plants were in the $\mathrm{V}_{4}$ stage (three fully expanded trifoliate leaves). The applications of the foliar $\mathrm{N}$ treatments were completed in the $\mathrm{R}_{5}$ (pre-flowering) development stage, i.e., on 10/9/2012 for irrigated 2012, on 4/7/2013 for rainfed 2013, and on 4/10/2013 for irrigated 2013, always in the early hours of the morning. Foliar N treatments were applied with Pulverizador Pesquisa (Herbicat, Catanduva, São Paulo, Brazil), a handheld $\mathrm{CO}_{2}$-pressurized sprayer equipped with four 0.5-m-spaced nozzles that, together, were calibrated to deliver $200 \mathrm{~L} \mathrm{ha}^{-1}$ solution. As the fertilizer Coron 25-0-0 plus $0.5 \%$ B has B in its constitution, to equal the amount of this micronutrient in all treatments, the amount applied by boric acid spray was compensated.

During common bean growth, the phytosanitary management included the application of: 0.1 and $0.45 \mathrm{~kg}$ a.i. ha ${ }^{-1}$ of the herbicides fluazifop-p-butyl and fomesafen, respectively; 0.05 and $0.45 \mathrm{~kg}$ a.i. $\mathrm{ha}^{-1}$ of the insecticides thiamethoxam+lambda-cyhalothrin and methamidophos; and 0.28, 0.05, and $0.4+1.0 \mathrm{~kg}$ a.i. $\mathrm{ha}^{-1}$ of the fungicides phytin hydroxide, azoxystrobin, and

Pesq. agropec. bras., Brasília, v.53, n.12, p.1329-1337, Dez. 2018 DOI: 10.1590/S0100-204X2018001200005 
thiophanate-methyl+chlorothalonil. In the irrigated experiments, water was supplied by a conventional sprinkler irrigation system (complementation irrigation), with the application of $7 \mathrm{~mm}$ per irrigation, always during the first hours of the morning, according to the crop needs.

Common bean shoot dry matter (DM) was evaluated in eight plants collected in each plot in the $R_{8}$ stage (pod filling). The plants were dried in a forced-air oven, at $65^{\circ} \mathrm{C}$, for 72 hours and then weighed. The material used to determine shoot DM was also ground and used for the analysis of total $\mathrm{N}$ content (Malavolta et al., 1997). Subsequently, N contents were multiplied by $\mathrm{DM}$ and by the plant population in each plot to calculate the amount of $\mathrm{N}$ accumulated $\left(\mathrm{kg} \mathrm{ha}^{-1}\right)$.

Harvests were performed on 11/26/2012 for the experiment irrigated 2012, on 5/15/2013 for rainfed 2013, and on 6/4/2013 for irrigated 2013. Yield components (number of pods per plant, number of grains per pod, and 100-grain weight) were assessed in eight plants per plot on the eve of harvest. The final plant population and grain yield $\left(\mathrm{kg} \mathrm{ha}^{-1}\right)$ were determined in two 3-m long rows per plot. The data for 100-grain weight and grain yield were corrected to $13 \%$ humidity.

Grain samples were dried in a forced-air oven, at $65^{\circ} \mathrm{C}$, for 72 hours and ground for the analysis of total N content (Malavolta et al., 1997). Crude protein content in the grains was obtained by multiplying the $\mathrm{N}$ content by 6.25 , whereas crude protein yield $\left(\mathrm{kg} \mathrm{ha}^{-1}\right)$ was calculated by multiplying the value of crude protein content by the grain yield (in DM) of the corresponding plot.

The data were subjected to the analysis of variance. The means of the growing environments (experiments) and of the $\mathrm{N}$ treatments applied to leaves were compared by Tukey's test, at 5\% probability. The effects of topdressing $\mathrm{N}$ rates were evaluated by the regression analysis. The statistical software package used was Sisvar (Ferreira, 2011).

\section{Results and Discussion}

In general, the growing environment (experiment) greatly influenced the agronomic characteristics of the common bean crop (Tables 1 and 2). However, there was no significant interaction between growing environment and foliar $\mathrm{N}$ application or between foliar
$\mathrm{N}$ application and soil (topdressing) $\mathrm{N}$ rate for any variable.

The soil and foliar applications of $\mathrm{N}$ did not influence the final plant population (Table 1). Smaller plant populations were obtained in the experiments rainfed 2013 and irrigated 2013, compared with irrigated 2012. Since the number of seeds used in all experiments was the same, these results may be due to the lower germination and vigor of the seeds or to growth conditions, including soil texture and organic matter content, water availability, quantity and type of straw mulching on soil surface, and plantability. According to Souza et al. (2002), populations of 120,000-300,000 plants per hectare do not alter the grain yield of the common bean crop. This would be attributed to the compensatory capacity of the primary yield components of common bean, especially in cultivars with indeterminate growth habit (type II/III), such as Pérola, resulting in equivalent grain yields for different plant populations (Arf et al., 2011).

There was a significant interaction between growing environment and topdressing $\mathrm{N}$ rate regarding shoot DM accumulation (Table 1). In general, in the experiments irrigated 2012 and irrigated 2013, common bean accumulated higher amounts of shoot DM (Figure $2 \mathrm{~A}$ ), corresponding to 5,464 and $4,886 \mathrm{~kg}$ $\mathrm{ha}^{-1}$, respectively, which were, on average, $45 \%$ higher than the shoot DM accumulation in rainfed 2013 (Table 1). The greater plant growth in the irrigated experiments was due to soil fertility, particularly the higher availability of $\mathrm{P}, \mathrm{Ca}$, and $\mathrm{Mg}$, and to an adequate water supply. In the experiment rainfed 2013, only topdressing $\mathrm{N}$ fertilization increased the amount of shoot DM accumulated by common bean up to the estimated rate of $127 \mathrm{~kg} \mathrm{ha}^{-1}$ (Figure $2 \mathrm{~A}$ ). According to Carvalho et al. (2016), under water deficit conditions, especially in the vegetative stages, common bean growth is reduced. The periods without rain at the beginning and end of March and at the end of April (Figure 1) may have led to lower DM production per plant in the experiment rainfed 2013, even though the plant population was lower than that of irrigated 2012 (Table 1). It should be pointed out that greater $\mathrm{N}$ availability allows a greater adaptation of the common bean plant to water deficit stress, minimizing its effect (Rashidi et al., 2015), which may justify the higher accumulation of DM in response to topdressing $\mathrm{N}$ rates in rainfed 2013 (Figure $2 \mathrm{~A}$ ). However, foliar $\mathrm{N}$ 
application did not interfere with the accumulation of plant DM (Table 1).

The lowest shoot $\mathrm{N}$ content was observed in the irrigated experiments, i.e., in those that produced higher amounts of shoot DM (Table 1), which may be attributed to a dilution effect. According to Lemaire et al. (2008), the dilution effect of $\mathrm{N}$ in plants may be due to the increase in the amount of shoot DM accumulation. Regardless of the growing environment, topdressing $\mathrm{N}$ fertilization linearly increased $\mathrm{N}$ content in the shoot of the common bean crop (Figure $2 \mathrm{~B}$ ). Although the $\mathrm{N}$ content of the plants grown in the experiment rainfed 2013 was higher than that of those in the irrigated experiments, the amount of $\mathrm{N}$ accumulated was lower, probably because of the lower amount of shoot DM produced under this growth condition (Table 1). Topdressing $\mathrm{N}$ fertilization linearly increased the amount of $\mathrm{N}$ accumulated in the shoot of the common bean crop (Figures 2 B and C). Souza et al. (2011), Perez et al. (2013), and Maia et al. (2017) also found a positive relationship between the amount of $\mathrm{N}$ in the common bean shoot and the application of increasing topdressing $\mathrm{N}$ rates, which they associated with a greater shoot DM accumulation. In the present study, foliar $\mathrm{N}$ application did not interfere with $\mathrm{N}$ content and accumulation in the shoot of common bean in the $\mathrm{R}_{8}$ stage (Table 1).

The experiment rainfed 2013 resulted in the lowest number of pods per plant, number of grains per pod, and 100-grain weight (Table 2), which is probably related to the lower availability of $\mathrm{P}, \mathrm{Ca}$, and $\mathrm{Mg}$ in the soil and to the lower water availability (Figure 1), limiting plant growth (Table 1). The number of pods per plant linearly increased due to topdressing $\mathrm{N}$ fertilization (Figure 3 A). It should be highlighted that foliar $\mathrm{N}$ application did not significantly affect any yield component (Table 2), whereas topdressing $\mathrm{N}$ fertilization had no significant effect on the number of grains per pod and 100-grain weight. The number of pods per plant is usually the yield component of the common bean crop most affected by $\mathrm{N}$ nutrition; therefore, when the plant presents deficiency of this nutrient, it produces fewer lateral branches and, consequently, fewer flowers and pods (Kaneko et al., 2010; Soratto et al., 2011, 2014, 2017).

Common bean grain yield was affected by the growing environment $\times$ topdressing $\mathrm{N}$ fertilization interaction (Table 2). The highest grain yield was obtained in the experiment irrigated 2012 (Table 2), possibly due to the highest plant population and number of pods per plant (Tables 1 and 2). Linear increases

Table 1. Final plant population, dry matter (DM), nitrogen content, and amount of $\mathrm{N}$ accumulated in the shoot in the $\mathrm{R}_{8}$ stage (pod filling) of the common bean crop (Phaseolus vulgaris) due to foliar $\mathrm{N}$ application, in three experiments (environments) ${ }^{(1)}$.

\begin{tabular}{|c|c|c|c|c|}
\hline Treatment $^{(2)}$ & $\begin{array}{c}\text { Plant population } \\
\text { (plants per hectare) }\end{array}$ & $\begin{array}{c}\text { Shoot DM } \\
\text { (grams per plant) }\end{array}$ & $\begin{array}{c}\mathrm{N} \text { content in } \\
\text { shoot } \mathrm{DM}\left(\mathrm{g} \mathrm{kg}^{-1}\right)\end{array}$ & $\begin{array}{l}\mathrm{N} \text { accumulated } \\
\text { in shoot }\left(\mathrm{kg} \mathrm{ha}^{-1}\right)\end{array}$ \\
\hline \multicolumn{5}{|l|}{ Environment (E) } \\
\hline Irrigated 2012 & $223,940 \mathrm{a}$ & $24.4 \mathrm{~b}$ & $23.6 b$ & $129.7 \mathrm{a}$ \\
\hline Rainfed 2013 & $177,083 b$ & $16.0 \mathrm{c}$ & $26.1 \mathrm{a}$ & $74.5 \mathrm{c}$ \\
\hline Irrigated 2013 & $161,819 \mathrm{c}$ & $30.2 \mathrm{a}$ & $23.8 \mathrm{~b}$ & $115.6 \mathrm{~b}$ \\
\hline \multicolumn{5}{|l|}{ Foliar N (NF) } \\
\hline Control & $187,700 \mathrm{a}$ & $22.6 \mathrm{a}$ & $24.8 \mathrm{a}$ & $105.2 \mathrm{a}$ \\
\hline $2.5 \mathrm{~kg} \mathrm{ha}^{-1} \mathrm{~N}-\mathrm{CU}$ & $191,929 a$ & $22.8 \mathrm{a}$ & $24.3 \mathrm{a}$ & $104.6 \mathrm{a}$ \\
\hline $5.0 \mathrm{~kg} \mathrm{ha}^{-1} \mathrm{~N}-\mathrm{CU}$ & $187,762 \mathrm{a}$ & $24.4 \mathrm{a}$ & $23.8 \mathrm{a}$ & $106.3 \mathrm{a}$ \\
\hline $2.5 \mathrm{~kg} \mathrm{ha}^{-1} \mathrm{~N}-\mathrm{SR}$ & $185,494 a$ & $23.7 \mathrm{a}$ & $25.2 \mathrm{a}$ & $109.9 \mathrm{a}$ \\
\hline $5.0 \mathrm{~kg} \mathrm{ha}^{-1} \mathrm{~N}-\mathrm{SR}$ & $185,185 \mathrm{a}$ & 24.1a & $24.4 \mathrm{a}$ & $107.0 \mathrm{a}$ \\
\hline $\mathrm{E} \times \mathrm{NF}$ & ns & ns & ns & ns \\
\hline $\mathrm{E} \times \mathrm{N}$ soil $(\mathrm{NS})$ & ns & $*$ & ns & ns \\
\hline $\mathrm{NF} \times \mathrm{NS}$ & ns & $\mathrm{ns}$ & ns & ns \\
\hline $\mathrm{E} \times \mathrm{NF} \times \mathrm{NS}$ & $\mathrm{ns}$ & $\mathrm{ns}$ & $\mathrm{ns}$ & $\mathrm{ns}$ \\
\hline Coefficient of variation (\%) & 11.5 & 16.9 & 13.8 & 27.5 \\
\hline
\end{tabular}

(1) Means followed by equal letters, in the columns within each factor (experiment/environment and foliar N), do not differ by Tukey's test, at $5 \%$ probability. ${ }^{(2)} \mathrm{N}-\mathrm{CU}$, nitrogen as conventional urea; $\mathrm{N}-\mathrm{SR}$, nitrogen as slow-release fertilizer based on urea-formaldehyde solution (Coron $25-0-0$ plus $0.5 \%$ B). *Significant by the F-test, at $5 \%$ probability. ${ }^{\text {ns }}$ Nonsignificant. 

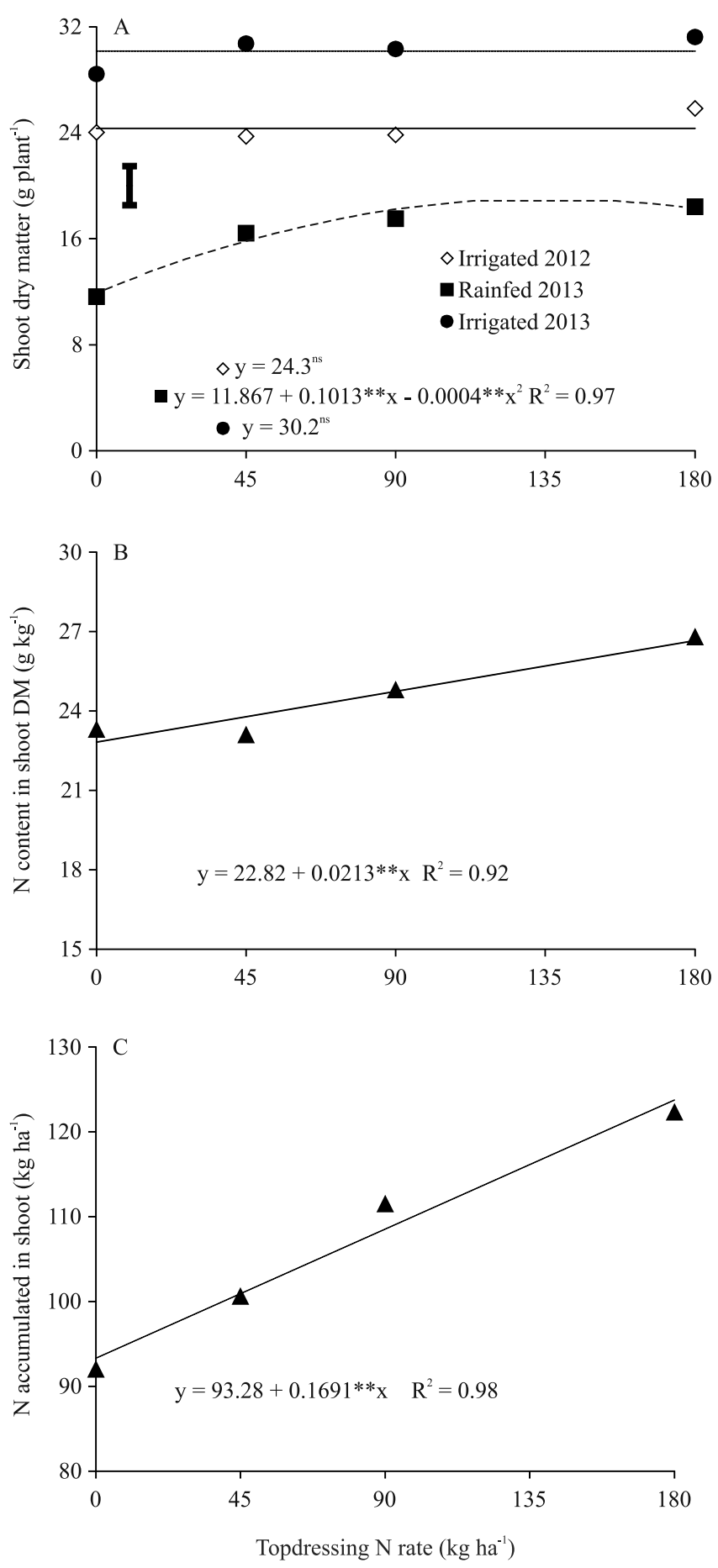

Figure 2. Dry matter (A), $\mathrm{N}$ content (B), and amount of $\mathrm{N}$ accumulated (C) in the shoot of common bean (Phaseolus vulgaris) crop in function of topdressing $\mathrm{N}$ rates, on average of five foliar-applied $\mathrm{N}$ treatments. Black triangles represent average of three experiments (environments). * and **Significant by the t-test, at 5 and $1 \%$ probability, respectively. Vertical bars indicate the least significant difference to separate experiments in a same topdressing $\mathrm{N}$ rate by Tukey's test, at 5\% probability. were observed in common bean grain yield due to topdressing $\mathrm{N}$ fertilization in the experiments irrigated 2012 and rainfed 2013, but were more significant in rainfed 2013, which showed a $41 \%\left(730 \mathrm{~kg} \mathrm{ha}^{-1}\right)$ increase (Figure 3 B). In the experiment irrigated 2013, grain yield was increased by topdressing $\mathrm{N}$ fertilization up to the estimated rate of $124 \mathrm{~kg} \mathrm{ha}^{-1}$. Crusciol et al. (2007), Kaneko et al. (2010), Soratto et al. (2014), Amaral et al. (2016), and Soratto et al. (2017) also reported increases in the grain yield of common bean due to soil-applied $\mathrm{N}$ fertilization, which was related to the expressive effect of this nutrient on plant growth and fruiting. The foliar application of $5.0 \mathrm{~kg} \mathrm{ha}^{-1} \mathrm{~N}-\mathrm{SR}$ resulted in the highest grain yield, with an increase of $395 \mathrm{~kg} \mathrm{ha}^{-1}(15.7 \%)$ compared with the control and of $253 \mathrm{~kg} \mathrm{ha}^{-1}(9.5 \%)$ with the treatment with $2.5 \mathrm{~kg} \mathrm{ha}^{-1}$ $\mathrm{N}-\mathrm{CU}$. Although not significant, the small increases in the yield components number of pods per plant, number of grains per pod, and 100-grain weight led to this result. Soratto et al. (2011) also found an increase in common bean grain yield due to foliar $\mathrm{N}$ application during the reproductive stages of the crop, but only in the absence of topdressing $\mathrm{N}$ fertilization. Roberts et al. (2006) verified a higher cotton lint yield with the application of $0.95 \mathrm{~kg} \mathrm{ha}^{-1} \mathrm{~N}-\mathrm{SR}$ (Coron), compared with $11.2 \mathrm{~kg} \mathrm{ha}^{-1} \mathrm{~N}-\mathrm{CU}$. These results may be related to the characteristics of the N-SR source, which presents lower salinity, lower phytotoxicity, and allows higher $\mathrm{N}$ uptake by plants (Roberts et al., 2006).

Crude protein content in the grains was influenced by growing environment and topdressing $\mathrm{N}$ fertilization (Table 2 and Figure $3 \mathrm{C}$ ). Higher protein contents were observed in the experiments rainfed 2013 and irrigated 2013 , i.e., those with a lower grain yield. However, the highest protein yield was found in irrigated 2012 due to the higher grain yield produced in this experiment (Table 2). Regardless of the growing environment and foliar $\mathrm{N}$ application, topdressing $\mathrm{N}$ fertilization linearly increased protein content and yield (Figures $3 \mathrm{C}$ and D). The foliar application of 2.5 or $5.0 \mathrm{~kg} \mathrm{ha}^{-1} \mathrm{~N}-\mathrm{SR}$ resulted in the highest protein yields, differing from the control, regardless of the growing environment and topdressing $\mathrm{N}$ fertilization. Soratto et al. (2011) found that foliar $\mathrm{N}$ application in the $\mathrm{R}_{5}+\mathrm{R}_{7}$ stages increased the crude protein content and yield of the common bean crop only in the absence of topdressed $\mathrm{N}$ fertilization. However, in the present study, there was no interaction between these factors, i.e., it was possible to increase 
Table 2. Number of pods per plant, number of grains per pod, 100-grain weight, grain yield, crude protein content in grains, and protein yield of the common bean (Phaseolus vulgaris) crop due to foliar $\mathrm{N}$ application, in three experiments (environments) ${ }^{(1)}$.

\begin{tabular}{|c|c|c|c|c|c|c|}
\hline Treatment $^{(2)}$ & $\begin{array}{c}\text { Pods per } \\
\text { plant }\end{array}$ & $\begin{array}{l}\text { Grains per } \\
\text { pod }\end{array}$ & $\begin{array}{l}\text { 100-grain } \\
\text { weight }(\mathrm{g})\end{array}$ & $\begin{array}{c}\text { Grain yield } \\
\left(\mathrm{kg} \mathrm{ha}^{-1}\right)\end{array}$ & $\begin{array}{l}\text { Protein content in } \\
\text { grains }\left(\mathrm{g} \mathrm{kg} \mathrm{k}^{-1}\right)\end{array}$ & $\begin{array}{c}\begin{array}{c}\text { Protein yield } \\
\left(\mathrm{kg} \mathrm{ha}^{-1}\right)\end{array} \\
\end{array}$ \\
\hline \multicolumn{7}{|l|}{ Environment (E) } \\
\hline Irrigated 2012 & $13.8 \mathrm{a}$ & $4.9 \mathrm{a}$ & $26.4 \mathrm{a}$ & $3,342 \mathrm{a}$ & $191.4 b$ & $556 a$ \\
\hline Rainfed 2013 & $12.4 \mathrm{~b}$ & $4.3 \mathrm{~b}$ & $24.6 b$ & $2,169 \mathrm{c}$ & $223.8 \mathrm{a}$ & $424 c$ \\
\hline Irrigated 2013 & $13.4 \mathrm{ab}$ & $4.9 \mathrm{a}$ & $26.4 \mathrm{a}$ & $2,699 \mathrm{~b}$ & 225.1a & $527 \mathrm{~b}$ \\
\hline \multicolumn{7}{|l|}{ Foliar N (NF) } \\
\hline Control & $12.5 \mathrm{a}$ & $4.6 \mathrm{a}$ & $25.6 \mathrm{a}$ & $2,525 \mathrm{c}$ & $211.9 \mathrm{a}$ & $462 b$ \\
\hline $2.5 \mathrm{~kg} \mathrm{ha}^{-1} \mathrm{~N}-\mathrm{CU}$ & $12.8 \mathrm{a}$ & $4.7 \mathrm{a}$ & $25.7 \mathrm{a}$ & $2,667 b c$ & 215.1a & $493 \mathrm{ab}$ \\
\hline $5.0 \mathrm{~kg} \mathrm{ha}^{-1} \mathrm{~N}-\mathrm{CU}$ & $13.2 \mathrm{a}$ & $4.7 \mathrm{a}$ & $25.9 \mathrm{a}$ & $2,747 \mathrm{ab}$ & $214.8 \mathrm{a}$ & $503 \mathrm{ab}$ \\
\hline $2.5 \mathrm{~kg} \mathrm{ha}^{-1} \mathrm{~N}-\mathrm{SR}$ & $13.7 \mathrm{a}$ & $4.7 \mathrm{a}$ & $25.8 \mathrm{a}$ & $2,824 \mathrm{ab}$ & $213.0 \mathrm{a}$ & $520 \mathrm{a}$ \\
\hline $5.0 \mathrm{~kg} \mathrm{ha}^{-1} \mathrm{~N}-\mathrm{SR}$ & $13.8 \mathrm{a}$ & $4.8 \mathrm{a}$ & $26.2 \mathrm{a}$ & $2,919 \mathrm{a}$ & $212.4 \mathrm{a}$ & $534 \mathrm{a}$ \\
\hline $\mathrm{E} \times \mathrm{NF}$ & ns & ns & ns & ns & ns & ns \\
\hline $\mathrm{E} \times \mathrm{N}$ soil $(\mathrm{NS})$ & ns & ns & ns & $*$ & ns & ns \\
\hline $\mathrm{NF} \times \mathrm{NS}$ & ns & ns & ns & ns & ns & ns \\
\hline $\mathrm{E} \times \mathrm{NF} \times \mathrm{NS}$ & $\mathrm{ns}$ & ns & ns & ns & ns & ns \\
\hline Coefficient of variation (\%) & 21.7 & 7.6 & 4.6 & 13.8 & 8.1 & 15.1 \\
\hline
\end{tabular}

${ }^{(1)}$ Means followed by equal letters, in the columns within each factor (experiment/environment and foliar N), do not differ by Tukey's test, at $5 \%$ probability. ${ }^{(2)} \mathrm{N}-\mathrm{CU}$, nitrogen as conventional urea; N-SR, nitrogen as slow-release fertilizer based on urea-formaldehyde solution (Coron $25-0-0$ plus $0.5 \%$ B)


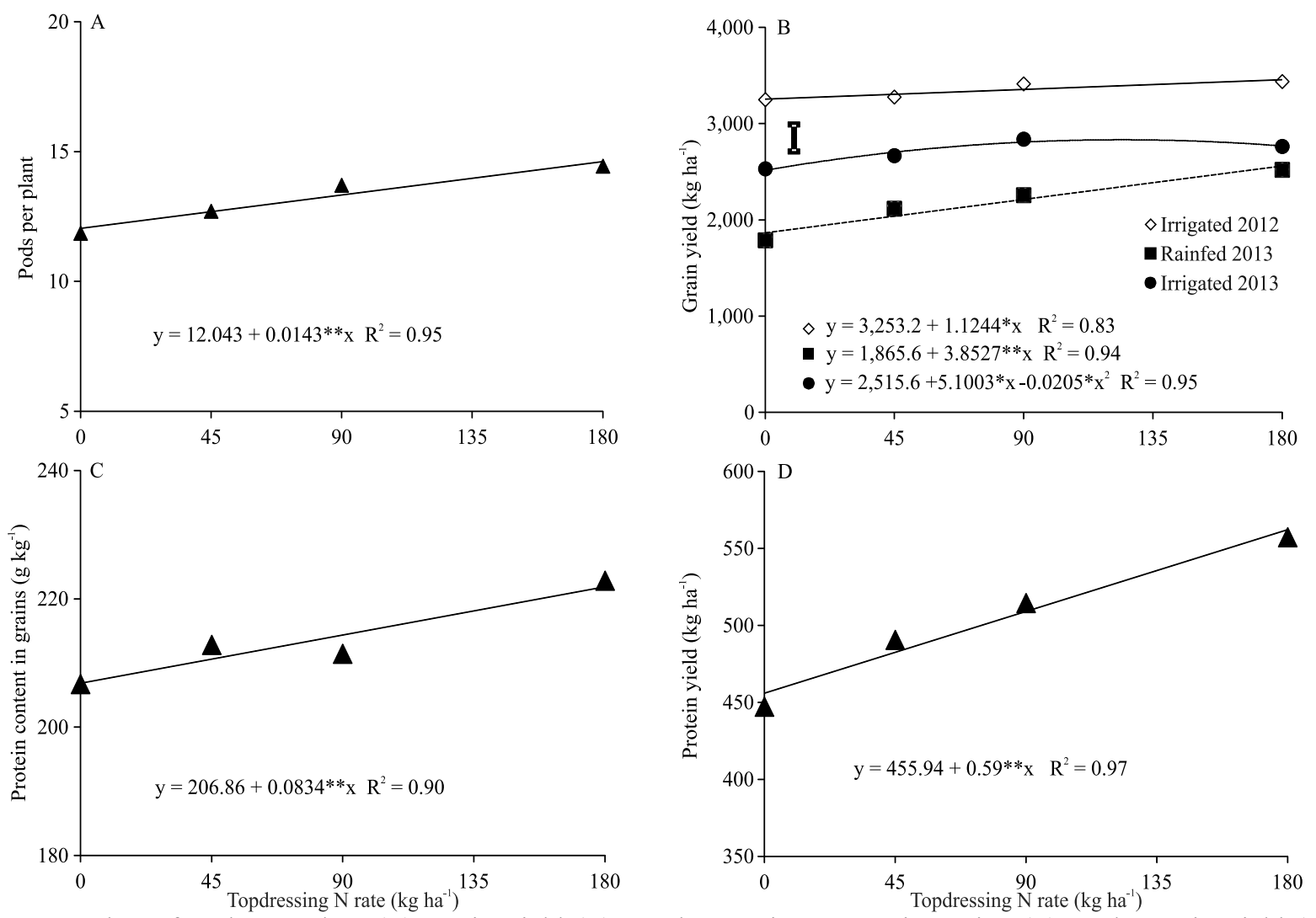

Figure 3. Number of pods per plant (A), grain yield (B), crude protein content in grains (C), and protein yield (D) of common bean (Phaseolus vulgaris) crop in function of topdressing $\mathrm{N}$ rates, on average of five foliar-applied $\mathrm{N}$ treatments. Black triangles represent average of three experiments (environments). ${ }^{*}$ and ${ }^{* *}$ Significant by the t-test, at 5 and $1 \%$ probability, respectively. Vertical bars indicate the least significant difference to separate experiments in a same topdressing $\mathrm{N}$ rate by Tukey's test, at $5 \%$ probability. 
the protein yield of the common bean crop with the foliar application of N-SR (Coron 25-0-0 plus 0.5\% B), regardless of the topdressing $\mathrm{N}$ rate (Table 2).

\section{Conclusions}

1. Topdressing $\mathrm{N}$ fertilization, at a rate between 124 and $180 \mathrm{~kg} \mathrm{ha}^{-1}$, increases shoot $\mathrm{N}$ content and accumulation, number of pods per plant, grain yield, and protein content and yield of the common bean (Phaseolus vulgaris) crop.

2. Regardless of the growing environment and topdressing $\mathrm{N}$ fertilization, foliar $\mathrm{N}$ application, via conventional urea and using the highest rate, increases common bean grain yield, whereas the foliar application of $\mathrm{N}$ as slow-release urea-formaldehyde increases grain and protein yields.

\section{Acknowledgments}

To Conselho Nacional de Desenvolvimento Científico e Tecnológico (CNPq), for scholarships to the first and second authors.

\section{References}

ALMEIDA, C. de; CARVALHO, M.A.C. de; ARF, O.; SÁ, M.E. de; BUZETTI, S. Uréia em cobertura e via foliar em feijoeiro. Scientia Agricola, v.57, p.293-298, 2000. DOI: 10.1590/S010390162000000200016.

AMARAL, C.B. do; PINTO, C.C.; FLÔRES, J. de A.; MINGOTTE, F.L.C.; LEMOS, L.B.; FORNASIERI FILHO, D. Produtividade e qualidade do feijoeiro cultivado sobre palhadas de gramíneas e adubado com nitrogênio em plantio direto. Pesquisa Agropecuária Brasileira, v.51, p.1602-1609, 2016. DOI: 10.1590/ s0100-204x2016000900060.

ARF, M.V.; BUZETTI, S.; ARF, O.; KAPPES, C.; FERREIRA, J.P.; GITTI, D. de C.; YAMAMOTO, C.J.T. Fontes e épocas de aplicação de nitrogênio em feijoeiro de inverno sob sistema plantio direto. Pesquisa Agropecuária Tropical, v.41, p.430-438, 2011. DOI: 10.5216/pat.v41i3.9706.

BORDIN, L.; FARINELLI, R.; PENARIOL, F.G.; FORNASIERI FILHO, D. Sucessão de cultivo de feijão-arroz com doses de adubação nitrogenada após adubação verde, em semeadura direta. Bragantia, v.62, p.417-428, 2003. DOI: 10.1590/S000687052003000300008 .

CARVALHO, J.J.; SAAD, J.C.C.; TEIXEIRA, M.B.; ALVES JÚNIOR, J.; DI CAMPOS, M.S.D.; HORSCHUTZ, A.C.O.; CUNHA, F.N. Growth and production of common bean in direct seeding under irrigated deficit condition. African Journal of Agricultural Research, v.11, p.2841-2848, 2016. DOI: 10.5897/ AJAR2016.11106.
CONAB. Companhia Nacional de Abastecimento. Série histórica das safras. Available at: < https://www.conab.gov.br/info-agro/ safras/serie-historica-das-safras>. Accessed on: July 32017.

CRUSCIOL, C.A.C.; SORATTO, R.P.; SILVA, L.M. da.; LEMOS, L.B. Fontes e doses de nitrogênio para o feijoeiro em sucessão a gramíneas no sistema plantio direto. Revista Brasileira de Ciência do Solo, v.31, p.1545-1552, 2007. DOI: 10.1590/S010006832007000600031.

FAO. Food and Agriculture Organization of the United Nations. Faostat: Crops: 2013. Available at: <http://faostat.fao.org/site/567/ DesktopDefault.aspx?PageID=567\#ancor $>$. Accessed on: July 4 2017.

FERREIRA, D.F. Sisvar: a computer statistical analysis system. Ciência e Agrotecnologia, v.35, p.1039-1042, 2011. DOI: 10.1590/ S1413-70542011000600001.

FORNASIERI FILHO, D; XAVIER, M.A.; LEMOS, L.B.; FARINELLI, R. Resposta de cultivares de feijoeiro comum à adubação nitrogenada em sistema de plantio direto. Científica, v.35, p.115-121, 2007.

KANEKO, F.H.; ARF, O.; GITTI, D. de C.; ARF, M.V.; FERREIRA, J.P.; BUZETTI, S. Mecanismos de abertura de sulcos, inoculação e adubação nitrogenada em feijoeiro em sistema plantio direto. Bragantia, v.69, p.125-133, 2010. DOI: 10.1590/S0006-87052010000100017.

LEMAIRE, G.; JEUFFROY, M.H.; GASTAL, F. Diagnosis tool for plant and crop $\mathrm{N}$ status in vegetative stage: theory and practices for crop N management. European Journal of Agronomy, v.28, p.614-624, 2008. DOI: 10.1016/j.eja.2008.01.005.

MAIA, S.C.M.; SORATTO, R.P.; LIEBE, S.M.; ALMEIDA, A.Q. de. Criteria for topdressing nitrogen application to common bean using chlorophyll meter. Pesquisa Agropecuária Brasileira, v.52, p.512-520, 2017. DOI: 10.1590/s0100-204x2017000700005.

MALAVOLTA, E.; VITTI, G.C.; OLIVEIRA, S.A. de. Avaliação do estado nutricional das plantas: princípios e aplicações. 2.ed. Piracicaba: Associação Brasileira para Pesquisa da Potassa e do Fosfato, 1997. 319p.

PEREZ, A.A.G.; SORATTO, R.P.; MANZATTO, N.P.; SOUZA, E. de F.C. de. Extração e exportação de nutrientes pelo feijoeiro adubado com nitrogênio, em diferentes tempos de implantação do sistema plantio direto. Revista Brasileira de Ciência do Solo, v.37, p.1276-1287, 2013. DOI: 10.1590/S0100-06832013000500017.

RASHIDI, S.; EBADI, A.; PARMOON, G.; JAHANBAKHSH, S.; HAGHIGHAT, Z. Effect of nitrogen source on bean growth under water deficit conditions. The Philippine Agricultural Scientist, v.98, p.279-285, 2015.

ROBERTS, R.K.; KENTY, M.M.; THOMAS, J.M.; HOWARD, D.D. Economic evaluation of soil and foliar applied nitrogen fertilization programs for cotton production. Journal of Cotton Science, v.10, p.193-200, 2006.

SANTOS, H.G. dos; JACOMINE, P.K.T.; ANJOS, L.H.C. dos; OLIVEIRA, V.A. de; LUBRERAS, J.F.; COELHO, M.R.; ALMEIDA, J.A. de; CUNHA, T.J.F.; OLIVEIRA, J.B. de. Sistema brasileiro de classificação de solos. 3.ed. rev. e ampl. Brasília: Embrapa, 2013. 353p. 
SORATTO, R.P.; CARVALHO, M.A.C. de; ARF, O. Teor de clorofila e produtividade do feijoeiro em razão da adubação nitrogenada. Pesquisa Agropecuária Brasileira, v.39, p.895-901, 2004. DOI: 10.1590/S0100-204X2004000900009.

SORATTO, R.P.; CATUCHI, T.A.; SOUZA, E. de F.C. de; GARCIA, J.L.N. Plant density and nitrogen fertilization on common bean nutrition and yield. Revista Caatinga, v.30, p.670678, 2017. DOI: 10.1590/1983-21252017v30n315rc.

SORATTO, R.P.; FERNANDES, A.M.; SANTOS, L.A. dos; JOB, A.L.G. Nutrient extraction and exportation by common bean cultivars under different fertilization levels: I - macronutrients. Revista Brasileira de Ciência do Solo, v.37, p.1027-1042, 2013. DOI: $10.1590 /$ S0100-06832013000400020.

SORATTO, R.P.; FERNANDES, A.M.; SOUZA, E. de F.C. de; SOUZA-SCHLICK, G.D. de. Produtividade e qualidade dos grãos de feijão em função da aplicação de nitrogênio em cobertura e via foliar. Revista Brasileira de Ciência do Solo, v.35, p.2019-2028, 2011. DOI: 10.1590/S0100-06832011000600018.

SORATTO, R.P.; PEREZ, A.A.G.; FERNANDES, A.M. Age of no-till system and nitrogen management on common bean nutrition and yield. Agronomy Journal, v.106, p.809-820, 2014. DOI: 10.2134/agronj13.0439.

SOUZA, A.B. de; ANDRADE, M.J.B. de; MUNIZ, J.A.; REIS, R.P. Populações de plantas e níveis de adubação e calagem para o feijoeiro (Phaseolus vulgaris L.) em um solo de baixa fertilidade. Ciência e Agrotecnologia, v.26, p.87-98, 2002.

SOUZA, E. de F.C. de; SORATTO, R.P.; PAGANI, F.A. Aplicação de nitrogênio e inoculação com rizóbio em feijoeiro cultivado após milho consorciado com braquiária. Pesquisa Agropecuária Brasileira, v.46, p.370-377, 2011. DOI: 10.1590/ S0100-204X2011000400005.

Received on August 8, 2017 and accepted on April 21, 2018 